\title{
A new species of Lithophane Hbn. (Lepidoptera, Noctuidae, Xyleninae) from southeastern United States
}

\author{
Vernon Antoine Brou Jr. ${ }^{\text {I, }}$, J. Donald Lafontaine ${ }^{2, \ddagger}$ \\ I 74320 Jack Loyd Road, Abita Springs, Louisiana 70420, USA 2 Canadian National Collection of Insects, \\ Arachnids, and Nematodes, Biodiversity Program, Agriculture and Agri-Food Canada, KW Neatby Bldg., \\ C.E.F., Ottawa, Ontario, Canada K1A 0C6 \\ † urn:lsid:zoobank.org:author:8E56BFCF-95B1-4722-B51F-78EA42365D13 \\ † urn:lsid:zoobank.org:author:2227A860-B768-4A51-8FE4-F1F3EB1CAA7F \\ Corresponding authors: Vernon A. Brou Jr. (vabrou@bellsouth.net), J. Donald Lafontaine \\ (LafontaineD@agr.gc.ca)
}

Academic editor: B. Christian Schmidt | Received 9 April 2009 | Accepted 23 April 2009 | Published 12 May 2009

urn:lsid:zoobank.org:pub:695C2170-652C-4675-804A-909EEF827994

Citation: Brou Jr VA, Lafontaine JD (2009) A new species of Lithophane Hbn. (Lepidoptera, Noctuidae, Xyleninae) from southeastern United States. In: Schmidt BC, Lafontaine JD (Eds) Contributions to the Systematics of New World Macro-Moths. ZooKeys 9: 11-20. doi: 10.3897/zookeys.9.158

\begin{abstract}
A new species of a noctuid moth in the genus Lithophane is described and illustrated. Lithophane abita Brou \& Lafontaine, sp. n. is known from the mid-Atlantic coastal states southward to Florida and the Gulf Coast states.
\end{abstract}

\section{Keywords}

Lepidoptera, Noctuidae, Lithophane, taxonomy, Alabama, Florida, Georgia, Louisiana, Maryland, Mississippi, North Carolina, winter moths

\section{Introduction}

Beginning in 1982, specimens of an undescribed species of Lithophane Hübner were captured at a single southeast Louisiana location using four to eight ultraviolet light traps operated at this location throughout the year regardless of weather conditions. Typical of numerous other winter-active moths, this new species is on the wing from

Copyright Vernon A. Brou Jr., J. Donald Lafontaine. This is an open access article distributed under the terms of the Creative Commons Attribution License, which permits unrestricted use, distribution, and reproduction in any medium, provided the original author and source are credited. 
late November until late March during an extended four month flight period in southeastern Louisiana. The adult, genitalia, and flight period of this species were previously illustrated (Brou 2005). This new species is described below.

\section{Lithophane abita Brou \& Lafontaine, sp. n.}

urn:lsid:zoobank.org:act:346FF58C-13A6-42AF-8560-71D612F30B98

Figs 1, 2, 5, 6, 7

Type material. Holotype $\widehat{O}$ (Fig.1): USA, Louisiana, St. Tammany Parish, 4.2 miles $(6.8 \mathrm{~km}) \mathrm{NE}$ of Abita Springs, Sec[tion] 24, T[ownship] 6 S [outh], R[ange] $12 \mathrm{E}$ [ast], 14 Feb. 2002, Vernon A. Brou Jr. Deposited in Canadian National Collection of Insects, Arachnids, and Nematodes (CNC), Ottawa, Canada.

Allotype + (Fig. 2): same locality and collector, 6 Dec. 2003. Deposited in CNC.

Paratypes: 145 Oे, 162 +. Alabama: Baldwin Co., Bon Secour National Wildlife Refuge, Sec.24, T9S,R2E, 18 Jan. 1993, Richard L. Brown (1 §). Florida: Alachua Co., Gainesville, 19 Dec. 1982, Edward C. Knudson (1 +); Alachua Co., Gainesville, 14 Feb. 2004, Jeffrey R. Slotten (1 q); Baker Co., Baxter, 29 Dec. 1990, John S. Kutis (1 ㅇ), Pinhook Swamp, 24 Feb. 2001, Hugo L. Kons Jr. (1 §̂); Collier Co., Golden Gate Estates 26 Jan. 1991, John S. Kutis (1 J); Duval Co., Jacksonville, 11 Mar. 1977, H.D. Baggett (1 + ); Hernando Co., 1 Mar. 2007, James T. Vargo (1 đ); Hillsborough Co., Lutz, Florida, 13 \& 22 Mar. 1911, F. W. Friday (2 +); Marion Co., Bay Lake, 0.5 mi. west of CR315, 7 Feb. 1991, John S. Kutis (1 Ô); Pasco Co., Clay Sink, Withlacoochee St. Forest, 6 Feb. 1991, John S. Kutis (1 P); Putnam Co., Putnam Hall Post Office, 3 Mar. 2004, Jeffrey R. Slotten (1 ठ); Sumpter Co., Withlacoochee St. Forest, 5 Feb. 1991, John S. Kutis (1 q), same location and collector, 9 Feb. 1991 (1 q), same location, 9 Feb. 1991, Richard M. Gillmore (1 q); Volusia Co., Cassadaga, 11

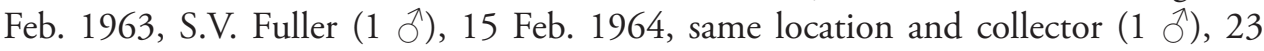
Feb. 1966, same location and collector (1 §, 1 ㅇ). Georgia: Long Co., Griffin Ridge Wildlife Management Area, NE of Altamaha River, $3 \mathrm{mi}$. SW of Ludowici, 3-4 Mar. 2004, James K. Adams (1 +). Louisiana: same locality and collector as for holotype, 21 Nov.-29 Mar. 1982-2009 (128 ठ̃, 138 O). Maryland: Calvert Co., Battle Creek Cypress Swamp, D. Williams/A. Brown, 14 Feb. 1990, H. Godwin Stevensen (2 ð); same locality and collector, Dwight F. Williams, 22 Oct. 1989 (1 Ö); Worcester Co., Pokomoke State Forest, 17 Oct. 1996 and 18 Oct. 1998, J. Glaser (3 o ); Worcester Co., Sturges Creek Cypress Swamp, 18 Oct. 1998, J. Glaser (1 $\left.{ }^{\prime}\right)$. Mississippi: Tishomingo Co., Tishomingo State Park, 34 35’ 54” N, 88 10’ 43” W, 3 Apr. 1998, Richard L. Brown $\left(\begin{array}{ll}1 & \text { đ}\end{array}\right)$. North Carolina: Carteret Co., Junction of Hwy 101 and Mill Creek Road, 22 Nov. 1973, J. Bolling Sullivan (1 q); Craven Co., North Harlow, 25 and 31 Mar. and 12 Nov. 1990, 13 and 18 Feb. and 20 Mar. 1991, J. Bolling Sullivan (3 J, 5 O)); Jones Co., Haywood Landing, 3 Apr. 1996 and 8 Mar. 2000, J. Bolling Sullivan (1 N $_{1} 1$ ); Pender Co., Shelter Gamelands, 5 Apr. 1996, J. Bolling Sullivan (1 +). Paratypes deposited in CNC; Florida State Collection of Arthropods, 


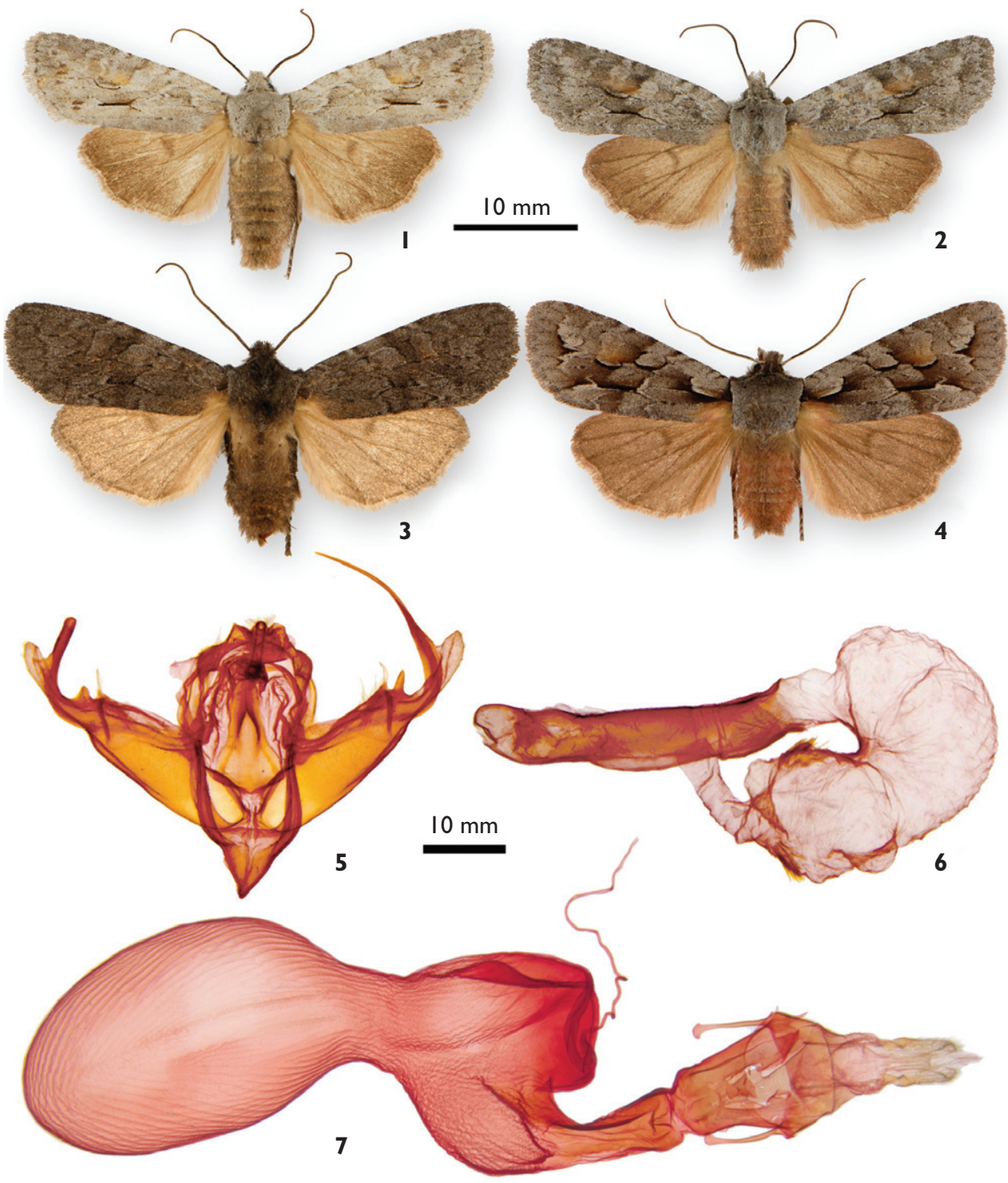

Figures I-7. Lithophane spp. I, L. abita Brou \& Lafontaine, male, holotype, USA, Louisiana, St. Tammany Parish, 4.2 miles $(6.8 \mathrm{~km}) \mathrm{NE}$ of Abita Springs. 2, L. abita Brou \& Lafontaine, female, allotype, USA, Louisiana, St. Tammany Parish, 4.2 miles $(6.8 \mathrm{~km})$ NE of Abita Springs. 3, L. adipel (Benjamin), USA, New Jersey, Lakehurst. 4, L. thaxteri Grote, male, Canada, New Brunswick, Edmundston. 5, L. abita Brou \& Lafontaine, male genital capsule. 6. L. abita Brou \& Lafontaine, male aedeagus with vesica everted. 7, L. abita Brou \& Lafontaine, female genitalia. 
Gainesville; Louisiana State Arthropod Museum, Baton Rouge; Mississippi Entomological Museum; Cornell University Collection, Ithaca, New York; National Museum of Natural History [USNM], Washington, DC; and the private collections of: James K. Adams, Robert J. Borth, Richard M. Gillmore, Edward C. Knudson, Hugo L. Kons Jr., Jeffrey R. Slotten, J. Bolling Sullivan, and the senior author. Primary types are designated with the words Holotype and Allotype in black text on red labels; paratypes are designated with the word Paratype in black text on yellow labels.

Etymology. The epithet is derived from the type locality near which all of the known Louisiana specimens have been taken, the town of Abita Springs, St. Tammany Parish, Louisiana, USA.

Diagnosis. Lithophane abita is a medium-sized species of Lithophane with a gray forewing and pinkish-fuscous hindwing. The forewing maculation tends to be pale and muted, except for a contrasting black line in the fold connecting the deeply zigzagged antemedial and postmedial lines. In these superficial characters, it has the appearance of some species in the Lithophane lepida Grote species-group of which only Lithophane adipel (Benjamin) (Fig. 3) occurs in southeastern United States. It is even more similar to Lithophane thaxteri Grote (Fig. 4), which like L. abita, has a brown flush to the area around the reniform spot and a black line defining the lower edge of the reniform spot, but $L$. thaxteri occurs in the boreal zone of Canada and in eastern United States as far south as New Jersey, but probably will not be found within the range of L. abita. The male genitalia of $L$. abita, however, are unique within the genus and the characteristic shape of the apices of the valves can be seen by brushing away some scales from the end of the abdomen. The digitus of the right valve projects beyond the apex of the valve as a long, curved, saber-like spine that is almost $2 / 3$ as long as the valve (Fig. 5); that of the left valve is short, stout, and apically blunt with the part of the digitus extending beyond the valve about $1 / 4$ of the length of that of the right valve. The spine-like process at the apex of the right valve can often be seen with the naked eye protruding from the end of the abdomen. The association of $L$. abita with bald cypress (Taxodium distichum Rich.), the probable larval host, is also unique within Lithophane.

Description. Males and females similar in all external characters except size. Head: color usually light to medium slate gray, occasional specimens dark gray; pronounced frontal tuft; a wide lateral black band of scales on center of head between eyes defined above and below by a bright white line of scales, upper line at a position above eye and below antenna: antenna filiform, simple, slender, and acuminate, similar gray in color, more so dorsally and near base of shaft; labial palp with black scales laterally and gray scales ventrally and dorsally; labial palp peppered with either black or gray scales with white tips; ventral surface of palp with long scales forming a pointed tuft projecting anteroventrally slightly beyond apex of palp. Thorax: dorsal color similar to that of head and forewing ground color except for wide transverse dark brown band on prothoracic collar with upper margin defined by distinct black line with upper scales forming a bright white line; anterior part of thorax with dorsal partially divided tuft of scales; ventral color of thorax light pinkish brown, gray, or fuscous, with area between legs and wings entirely black; outer side of foreleg coxa a mixture of black and white scales 
(appearing gray to naked eye), with a short group of longitudinal black scales emanating from base; scales on the inner side of coxa brownish gray with a fine longitudinal line of black scales; femur covered with black and white scales (appearing gray to naked eye) with black scales more concentrated near trochanter; scales on coxa of midleg a mixture of gray and white, except near trochanter, where scales form a band of black followed by a band of white; similar black and white bands continue along remainder of midleg femur, tibia, and tarsus; hindleg similar in color and appearance to midleg. Abdomen: dorsal color fuscous with pink suffusion throughout; ventral color same as dorsal. Forewing: dorsal ground color matching that on dorsum of head and thorax; maculation varying from strongly marked to barely distinguishable; weakly marked specimens appear to have been on the wing longer, but do not necessarily appear exceptionally worn; most specimens with very faint, sometimes barely distinguishable, bifurcating black basal dash; antemedial (am) line mostly faint, deeply zigzagged, defined in paler gray and partly bordered on outer edge by black, except in area of fold where am line sharply defined in black forming an outward projecting "V" that extends into prominent, black dash in fold parallel to lower margin of wing and extends to postmedial ( $\mathrm{pm}$ ) line; pm line deeply serrated but faint, partly defined by pale gray and dark gray scales; subterminal line also faintly defined in pale and dark gray but usually bordered in subterminal area by series of diffuse, dark-gray, wedge-shaped spots; terminal area concolorous with medial area, or very slightly darker with wing veins partly defined in black; terminal line incomplete, dark gray, usually stronger between veins; orbicular spot a rounded or slightly oblong paler gray shade defined mainly by the darker gray shading surrounding it; a prominent crescentic black line extends from outer lower edge of orbicular spot and around lower margin of reniform spot; reniform spot barely distinguishable as a paler gray outline above black line on lower margin of spot; forewing with fuscous-brown scales in area between reniform and orbicular spots, and in lower part of reniform. Ventral color of forewing pale luteous brown on basal half of wing, pinkish brown on distal half and forming a darker marginal shade; reniform spot diffuse, dark brown, usually crescent-shaped; terminal line defined by faint black scales accentuated with conspicuous black scales forming v-shaped wedges between veins; fringe gray. Wing length: male: $16.7 \mathrm{~mm}(15.7-18.0, \mathrm{n}=25)$; female: $17.1 \mathrm{~mm}(15.6-18.4, \mathrm{n}=25)$. Hindwing: dorsal color fuscous with pinkish suffusion throughout; fringe contrastingly lighter slate gray, especially at base of fringe; terminal line usually expressed as diffuse darker brown lines most often only between veins on outer margin of wing; discal spot crescentic, darker than ground color but barely discernable. Ventral color entirely light pink with numerous tiny brown scales sprinkled over entire surface; terminal line generally similar to that on dorsal surface; discal spot very large, brownish-black spot in center of wing; postmedial line a faint but discernable dark, broad line.

Male genitalia $(\mathrm{n}=6)$ : genital capsule (Fig. 5) with supporting ring modified, so enlarged vinculum and pleural sclerite occupy basal $2 / 3$ of ring, presumably to support greatly enlarged base of valve; tegumen proportionally reduced to dorsal $1 / 3$ of ring; uncus short, cylindrical, expanded at apex; juxta a very large diamond-shaped plate oc- 
cupying most of area inside genital ring; valves short and triangular, very large at base and tapering to narrow apex; valves asymmetrical; right sacculus large, twice as long as cucullus; cucullus reduced with sclerotized finger-like process at base of cucullus on dorsal margin of valve; apical part of cucullus reduced to rounded, almost membranous flap without any trace of a corona; digitus massive, arising from costal margin of valve, covering basal b of cucullus, then bending dorsally to project posterodorsally from end of valve as a long, tapered, saber-like spine; clasper reduced to Y-shaped sclerite at apex of valve with ampulla projecting beyond costal margin of valve as lightly sclerotized, finger-like process; left valve similar to right valve, except sacculus not as enlarged dorsally at base, costal process at base of cucullus triangular, part of left digitus projecting from valve $1 / 4$ as long as saber-like extension of right digitus, and apex of left digitus blunt and rounded. Aedeagus (Fig. 6) cylindrical, heavily sclerotized, about $6 \times$ as long as wide; vesica about $1 \frac{1 / 2}{2} \times$ as long as aedeagus; basal $1 / 6$ as wide as aedeagus; apical part inflated and sac-like, curving in an arc $180^{\circ}$ to project anteriorly; vesica with two short diverticula, one short preapical on dorsal surface and one on ventral surface at apex; apex of vesica with two subapical patches of spine-like cornuti, one dorsal and one ventral. Female genitalia $(\mathrm{n}=5)$ (Fig. 7$)$ : corpus bursae with prominent postmedial constriction giving it a figure 8-shape; without signa; posterior part of corpus bursae with short, lightly sclerotized, appendix bursae to left of ductus bursae; ductus bursae about $1 / 3$ as long as corpus bursae, sclerotized posteriorly but more lightly sclerotized anteriorly and wider at corpus bursae; ostium bursae sclerotized, tapered anteriorly, truncated abruptly at membranous connection with ductus bursae; anterior apophyses slightly shorter, but much stouter, than posterior apohyses, about $1 / 4 \times$ longer than ring of abdominal segment VIII; anal papillae lightly sclerotized, rounded at apex, about as long as membranous connection to abdominal segment VIII; covered by mixture of short and longer hair-like setae.

Biology and distribution. Within Louisiana, Lithophane abita is single brooded with adults on the wing from November 21 to March 29 (Fig. 8). Elsewhere the flight season extends from 17 October (Maryland) to early April (Mississippi and North Carolina). Lithophane abita has been confirmed from the states of Alabama, Florida, Georgia, Louisiana, Maryland, Mississippi, and North Carolina. The suspected host plant is bald cypress, Taxodium distichum Rich. In Maryland the three known localites are in bald cypress swamps within a few kilometers of the northernmost site of natu-

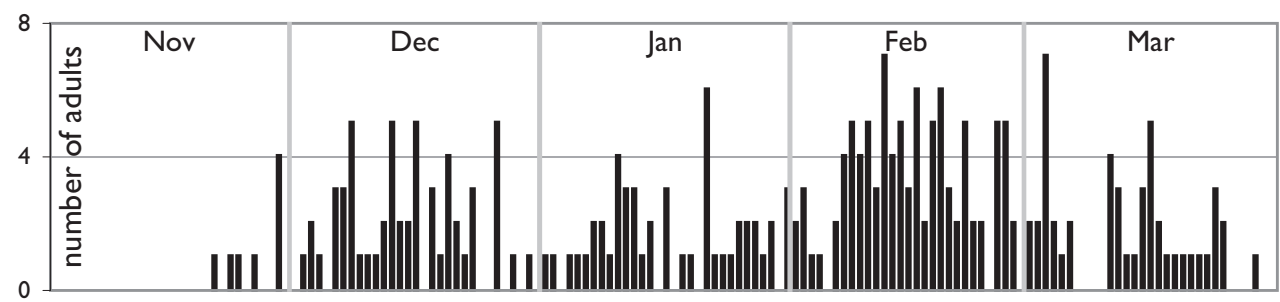

Figure 8. Seasonal occurrence of Lithophane abita at type locality (Abita Springs, Louisiana). 
rally occurring bald cypress trees. In Florida, this moth is often found in or very close to pond cypress domes (R. M. Gillmore, pers. comm.). A single Florida specimen was labeled as captured at fruit bait.

Remarks. R. M. Gillmore provided the authors with numerous additional Florida records acquired from various sources, from the counties already listed in the paratype series. These specimens are not included as paratypes due to their poor quality.

Within Louisiana, L. abita was captured using ultraviolet light traps only at the Abita Springs location despite 39 continuous years of collecting using the same collecting methods throughout the State. No species of Lithophane was previously recorded for Louisiana by Chapin and Callahan (1967), who published the only list of Noctuidae for the state. However, intensive collecting by the senior author at the type locality of $L$. abita has turned up about 10 Lithophane species, some requiring further study to confirm their identity. [move this and the next paragraph to beginning of Discussion section]

Reference to this undescribed species can be found dating back 44 years to Kimball's (1965) book on the Lepidoptera of Florida. Under the heading Lithophane sp., Kimball (1965: 93) states that [John G.] Franclemont is describing it. Kimball listed six specimens from the Florida counties of Alachua, Escambia, Hillsborough, and Jefferson with collecting dates on three of the specimens from Lutz, Hillsborough Co., dating back 93 years. The oldest specimens of L. abita we were able to find were captured 98 years ago in 1911, also at Lutz, Florida.

\section{Discussion}

Lithophane abita is apparently not closely related to any other species of Lithophane, although features of the male genitalic structure and suspected larval host plant suggest affinities to the L. lepida and L. gausapata groups (discussed below). Among the unique features of $L$. abita are: the strongly asymmetrical male valves; the greatly enlarged base of the valve with the corresponding enlargement of the vinculum and pleural sclerite, and reduction of the tegumen; the greatly reduced cucullus; the very small, mainly membranous, ampulla of the clasper; and the prominent constriction in the female corpus bursae. A phenogram (Fig. 9) based on the 'barcode' fragment of the mtDNA cox1 gene (Ratnasingham and Hebert 2007) illustrates the relationships among 39 of North American Lithophane. The results, in combination with genital structure, show the species of Lithophane arranged in nine species-groups. The L. abita-group (Group I) is associated with the L. signosa-group (Group II), although 4 \% divergent from any species in the L. signosa-group, which show intraspecific divergences of less than $1 \%$. There are no derived morphological character states shared by these two groups, so the association based on molecular data may merely be a product of the isolation of the L. abita-group from any other group of Lithophane rather than a phylogenetic association with the L. signosa-group. In the male genitalia of the $L$. signosa-group the cucullus is well developed with an apical corona and the digitus is 


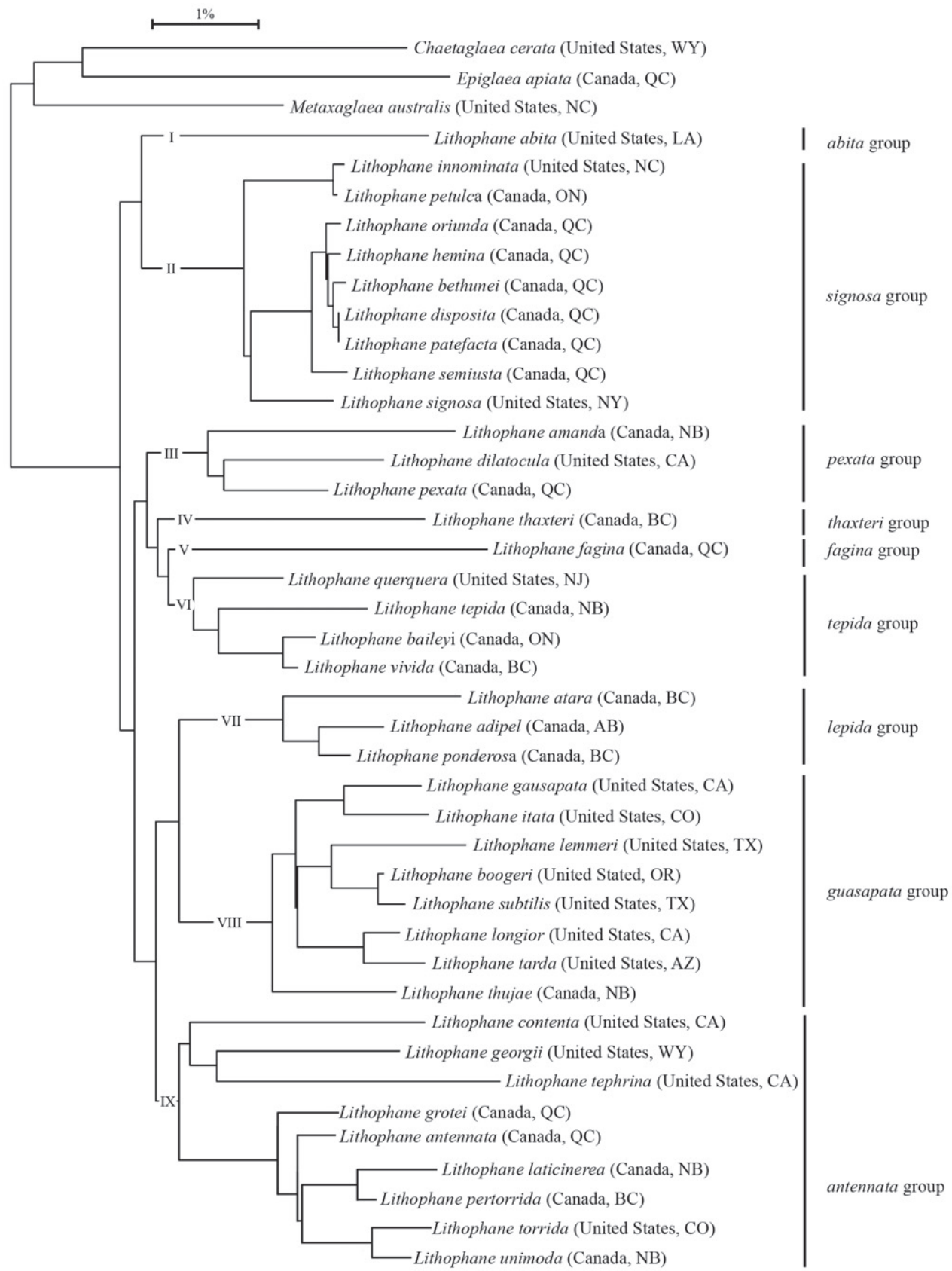

Figure 9. Phenogram of 39 North American Lithophane spp. based on the mtDNA 'barcode' fragment of $C O I$, constructed using the Neighbor-Joining method with the Kimura 2-parameter (K2P) algorithm implemented in BOLD (Ratnasingham and Hebert 2007). 
well developed. The next cluster in Figure 9 shows a loose association of four isolated species-groups of which the first three (L. pexata-group (III), L. thaxteri-group (IV), and L. fagina-group (V)) have male genitalia similar to those of the L. signosa-group. The last group in this cluster includes four species of the L. tepida-group (Group VI) in which the cucullus is reduced and the digitus forms an apical spine at the end of the valve. This is somewhat suggestive of the apex of the right valve of L. abita, but the two groups differ in all the other characters listed as being unique in the L. abitagroup. In groups VII, VIII, and IX the apex of the valve appears forked because the cucullus is reduced and apically narrow and the digitus forms a second short apical or subapical process. The first two of these groups have similar genitalia and feed on conifers as larvae with the L. lepida-group (Group VII) on pines (Pinaceae) and the L. gausapata-group (Group VIII) on various Cupressaceae. In the L. antennata-group (Group IX) the part of the digitus on the inner surface of the valve forms a rounded, ventrally serrated plate. Both the DNA results, and the many peculiarities of the genitalia, demonstrate the isolated position of the Lithophane abita-group within the genus. The suspected larval host plant and the reduction of the cucullus in the male genitalia suggest that L. abita is probably most closely related to the conifer-feeding groups (Groups VII and VIII). A phylogenetic analysis using morphological and molecular data would be informative, and may shed some light on the evolutionary relationship of L. abita to its congeners.

\section{Acknowledgements}

We thank the following individuals who supplied specimens, records, or aided in this project: James K. Adams, Robert A. Belmont, Charles W. Bordelon Jr., Robert J. Borth, Richard L. Brown, Richard M. Gillmore, John B. Heppner, Edward C. Knudson, Hugo L. Kons Jr., Michael G. Pogue, Dale F. Schweitzer, Jeffrey R. Slotten, J. Bolling Sullivan and James T. Vargo. We thank Jocelyn Gill for preparing the color plate and for assisting in the preparation of the genitalia slides and Paul Hebert and the other members of the Barcode of Life Project at the University of Guelph, Ontario, for providing DNA data. James K. Adams, B. Christian Schmidt, Dale F. Schweitzer, and J. Bolling Sullivan reviewed a draft of the manuscript and provided many helpful suggestions.

\section{References}

Brou Jr. VA (2005) An undescribed Lithophane from Louisiana. Southern Lepidopterists' News, 27: 9.

Chapin JB, Callahan PS (1967) A list of the Noctuidae (Lepidoptera, Insecta) collected in the vicinity of Baton Rouge, Louisiana. Proceedings of the Louisiana Academy of Sciences, 30: 39-48. 
Kimball CP (1965) Arthropods of Florida and neighboring land areas, Vol. 1: Lepidoptera of Florida, Division of Plant Industry, Florida Department of Agriculture, Gainesville. v + 363 pp., 26 plates.

Ratnasingham S, Hebert PDN (2007) Bold: The barcode of life data system. Molecular Ecological Notes, 7: 355-364. 